\title{
A phenomenon-driven approach to the study of value creation and organizational design issues in agri-business value chains
}

\section{Steiner, Bodo Ernst}

2017

Steiner , B E 2017 , ' A phenomenon-driven approach to the study of value creation and organizational design issues in agri-business value chains ' , Economia agro-alimentare , vol. 19 , no. 1 , pp. 89-118 . https://doi.org/10.3280/ECAG2017-001005

http://hdl.handle.net/10138/327939

https://doi.org/10.3280/ECAG2017-001005

unspecified

acceptedVersion

Downloaded from Helda, University of Helsinki institutional repository.

This is an electronic reprint of the original article.

This reprint may differ from the original in pagination and typographic detail.

Please cite the original version. 
A phenomenon-driven approach to the study of value creation and organizational design issues in agribusiness value chains

Steiner, B. E., 2017, In : Economia agro-alimentare. 19, 1, p. 89-11830 p.

\title{
A phenomenon-driven approach to the study of value creation and organizational design issues in agri-business value chains
}

\begin{abstract}
Guided by a phenomenon-driven research approach (Schwarz \& Stensaker 2016), this paper explores an apparent pre-occupation of the agri-business value chain literature with organizational design issues relative to a focus on value creation. The discussion of evidence from three sectors suggests that asymmetric distribution of market power, lack of trust, lack of effective use of residual claimancy, and lack of transparent and consumer-driven grading and certification institutions are key factors in the way of coordinated value creation, helping to explain why organizational design issues retain focus in efforts to drive value chain performance. Those interested in bringing back coordinated value creation into focus likely benefit from addressing the above key factors individually, yet the evidence also suggests that accounting for complementarities between physical infrastructure and institutions, and accounting for substitutability of institutionalized relationships and formal institutions bears additional performance potential for value chains.
\end{abstract}

Keywords: value creation, value chains, beef, medicinal and aromatic plants, non-timber forest products

JEL codes: $\quad$ Q13, Q18, M21, L66, D23 


\section{Introduction}

The concept of a value chain (VC) has been brought to the fore long ago by Michael Porter (Porter 1985). Porter's view depicts the firm as a collection of discrete, value creating activities and support activities. Taking into account more recent work, the notion of a VC has evolved in at least three ways. First, it could be regarded as a concept and analytical construct that helps to rationalize transfer prices and identify those steps in the vertical chain where most value is created and added (e.g. Besanko et al. 2009; Steiner 2007; Taylor 2005). A large number of analyses have taken a mostly strict strategic management accounting perspective and applied VC analysis (VCA), in an effort to segment a VC such that sources of differentiation and sources of costs can be identified. ${ }^{1}$ Second, the notion of a VC builds upon and emphasizes the close relationships between the functional strategies within a firm (e.g. product development strategy \& marketing strategy; Chopra et al. 2009). And third, since the VC begins with new product development (Chopra et al. 2009) that may occur outside of the firm responsible for marketing the final product, we could envisage the VC in terms of a set of independently owned firms which are connected through value-creating activities and contracts, both formal and informal (Steiner 2007; Besanko et al. 2009). What unites these views is the recognition that VCs capture flows of information, resources and products.

As a function of a more global and technologically demanding knowledge economy, as well as novel business climate regulations and pressures to specialize, we observe a continued surge of VCs and related organizational forms, including joint ventures, novel forms of supplier-customer partnerships and inter-firm collaborations (e.g. Ojasalo 2004; Ritter, Wilkinson and Johnston 2004; Gulati et al. 2005; Lutz and Ritter 2009; Reardon 2015). In line with this empirical observation that applies not only to the agri-food sector, we also observe that much of the academic research focus on agri-business VCs has been on optimal organizational design issues. ${ }^{2}$ Thus, the question arises whether the consumer perspective, and in particular our understanding of value creation as a driving force to 'pull-up' value chains, has been neglected in academic research and business practice. Priem (2007: 220) speaks of a "...long-ignored consumer lens on value creation", arguing that "... strategists cannot afford to focus solely on capturing exchange value while leaving to chance that use value will be experienced." (p. 233). Outside of the agribusiness literature, some work has focused on value creation through collaborative relationship management (e.g. Leek, Turnbull, and Naude 2004; Christopher \& Gattorna 2005) and customer relationship management (e.g. Zablah et al. 2004). However, even within this literature, we observe a limited attention to consumer-oriented firm collaborations and VCs (Priem and Butler 2001; Möller 2006; Priem 2007; Macharia et al. 2013; Anastasiadis et al. 2014).

\footnotetext{
${ }^{1}$ See the analyses by Shank \& Govindarajan (1992), Dekker (2003), Simons et al. (2003), Francis et al. (2008), Fearne et al. (2012), Ariyawardana et al. (2013), Maunahan et al. (2013), Kline et al. (2016) and Howieson et al. (2016).

${ }^{2}$ E.g., Wijnands \& Ondersteijn (2006), Gray et al. (2006), Gellynck \& Molnar (2009), Kottila (2009), Bahlmann \& Spiller (2009), Coronado et al. (2010), Uddin et al. (2010), Ali \& Kumar (2011), Bryceson \& Slaughter (2010), Piltan et al. (2014).
} 
This lack of focus in the literature on transforming resources and capabilities into customer value (Möller 2006) could, at first sight, be explained by the historical preoccupation of scholars with the traditional Resource-Based View (Barney 1991; Wernerfelt 1984) and with the positioning of the firm (Porter 1987), since both views focus largely on firm-internal, organizational issues where value is assumed to be determined externally (Lavie 2006; Priem 2007). As Priem (2007) emphasizes further, one of the key issues of these views is how members of a value system can increase their share of consumer payments received, at the expense of other system members, resulting in a zero-sum game that divides the given 'value-pie'. ${ }^{3}$ In contrast to this perspective, a focus on value-creation complements strategic positioning and resource re-combinations, leading to a growing 'value-pie'. ${ }^{4}$ Keeping this conceptual frame in mind, it appears nevertheless striking why the empirical literature seems to be characterized by alack of focus on coordinated value-creation relative to organizational design issues.

To explore this this, this paper takes a phenomenon-driven, problem-oriented research approach (Schwarz and Stensaker 2016; Van de Ven 2016), by capturing, documenting and conceptualizing this phenomenon in the context of the agri-business value chain literature and its empirical evidence. To the best of our knowledge, this approach has not been employed to analyses of agri-business VCs. In search for a robust answer, we aim for 'grounding the research phenomenon' (Van de Ven 2016) by contrasting evidence from agri-business VCs in sectors with well-established VCs (beef), with those of emerging VCs (medicinal plants/ non-timber forest products). We concentrate on these sectors first for conceptual reasons, because they fit Möller's (2006) distinction of a 'value system continuum' which is also employed to guide the following discussion. Furthermore, these sectors are chosen in view of their economic importance (OECD-FAO Agricultural outlook 2015-2024 for relevance of the beef sector) and in view of their relative limited attention in the VC literature thus far. Further, we concentrate on evidence since the early 1990s, as detailed empirical evidence and related theory constructs (e.g. transaction cost theory) have since developed most vibrantly.

The remainder of the article is structured as follows. Section 2 provides background to the phenomenon-driven research approach employed. This is followed by a conceptual discussion of value creation (section 3.1.), as the basis for contrasting empirical evidence from well-established VCs (section 3.2.) with evidence from emerging VCs (section 3.3.). Section 4 concludes.

\section{Methods: a phenomenon-driven research approach}

\footnotetext{
${ }^{3}$ Porter (1996) subsequently adjusted this notion of a zero-sum game, resulting in sustainable competitive advantage that goes beyond operational effectiveness.

${ }^{4}$ Following Tirole (1988) and Bowman and Ambrosini (2000), Priem (2007: 220) provides a cohesive view of value creation, which "...involves innovation that establishes or increases the consumer's valuation of the benefits of consumption (i.e., use value). When value is created, the consumer either (1) will be willing to pay for a novel benefit, (2) will be willing to pay more for something perceived to be better, or (3) will choose to receive a previously available benefit at a lower unit cost, which often results in a greater volume purchased. Thus, from the consumer's viewpoint, value creation involves increasing use value or decreasing exchange value, each of which can increase consumer surplus ...."
} 
"With the scholarly goal of building knowledge and developing ideas rather than a narrow focus on theory or data, it [phenomenon-driven research] is a doctrine founded in observable, discoverable phenomena. ... phenomenondriven researchers pay attention to an issue that motivates further exploration. As an ideas-led and interpretive way of researching, it is part of a broader conversation on a relevant problem." (Schwarz \& Stensaker, 2016: 245, 246).

Guided by a phenomenon-driven research approach, and based on a discovery that emerged during the research process on agri-business VCs, the following sections aim to explore an apparent lack of focus on value-creation in the context of agri-business VC research and practice. ${ }^{5}$ We follow Schwarz et al. (2016: 250) in using theory by linking empirically derived insight onto established bodies of literature, keeping theory in the background, to flesh out the phenomenon (257). At the same time, reviewing the literature is part of the approach to determine the scope, prevalence, and context of the phenomenon (van de Ven 2016: 2). The overall goal is to frame the research in terms of the importance of the phenomena to both academics and practitioners (Eisenhardt et al. 2007; Schwarz et al. 2016), aiming to ensure that the phenomenon is grounded in reality, and that its diagnosis is linked to the general case (here: organizational design issues; Lewin \& Minton 1986) of which it is a part (van de Ven 2016). We thus follow Schwarz et al. (2016: 245), who highlight that phenomenon-driven research is problem-oriented research that focuses on capturing, documenting, and conceptualizing organizational and managerial phenomena of interest in order to facilitate knowledge creation and advancement.

In the following sections, the attempt is to capture and conceptualize the phenomenon, aiming to provide some novel and practical management insights through existing theory frames. Recognizing the conceptual link between VCs and strategic alliances, it is also of interest to note that van Krogh et al. (2012: 278) highlight that previous work on alliance formation has identified a phenomenon-driven approach in the evolving literature on alliance formation, which stemmed from the accumulation, proliferation and significance of interfirm alliances (Gulati 1998; Lavie 2006). We take a similar view here, in that we observe an accumulation, proliferation and increasing significance of agri-business VCs in research and practice since the 1990's. This leads us to employ empirical evidence to highlight what we consider a relevant phenomenon (the pre-occupation with organizational design issues), while aiming to reconcile this within existing theory frameworks. Where appropriate, the analysis draws from transaction cost theory (Williamson 1985; 1993), incomplete contract theory (Hart 1995) social capital theory (e.g. Inkpen \& Tsang 2005; Bourdieu 1986) as well as the notion of absorptive capacity (Cohen \& Levinthal 1990; Zarah \& George 2002).

The following sections focus first on the conceptual underpinnings of value creation types and strategies, before contrasting empirical evidence from well-established VCs (beef) with that from emerging VCs (medicinal, aromatic plants and non-timber forest

\footnotetext{
${ }^{5}$ Schwarz et al. (2016: 252) highlight that there are at least three options of how a phenomenon can be introduced, one being to frame the motivation around discoveries that emerged during the research process.
} 
products), thereby following Möller's (2006: 922) distinction of a 'value system continuum' of well-established and emerging exchange markets.

\section{Evidence}

\subsection{Value creation strategies}

Priem (2007: 231) suggests to distinguish three broad categories of value creation strategies that can be developed using the consumer perspective: growing individual consumers' human capital, reducing demands on consumers, and focusing on human capital in multimember households. Value creation could also be fostered through valuebased marketing, which is centered on the attributes of a product or service, providing the basis for an identification of value drivers that can ultimately help to identify and build a customer-focused VC (Davidow and Malone 1992; Walters and Lancaster 1999). In contrast to such views on value creation, Möller (2006: 922) distinguishes a 'value system continuum' with three basic 'types of value-production', which he suggests influence the role of producers and customers and the competencies required from them: core value production in stable and well-established exchange markets (here: VCs), value-added value production via incremental innovation and change, and future value production via radical innovation and emerging networks (here: emerging VCs). Given this 'value system' perspective, it is unsurprising that for Möller (2006: 922), the "relational logic of value production", in terms of the competencies related to both suppliers and buyers, is highly important. This logic could also be viewed through the lens of the Resource-Based-View (RBV) of the firm (Barney 1991; Lavie 2006): What links both Priem's (2007) and Möller's (2006) view of value creation, the RBVs focus on resources and relationships (Lavie 2006) and the notion of dynamic capabilities (Zarah and George 2002), is the idea that a 'human filter' is required for value creation, i.e. that the exchange of human capital and thus labor competencies determine absorptive capacity (Cohen and Levintal 1990). This absorptive capacity could be regarded as a VC's key potential to exploit external knowledge for successful knowledge transfer, product commercialization and value creation. Yet to create value from such potential leads us to focus on organizational design issues: how can we achieve that potentially complementary assets are actually employed and therefore generate synergies from complementarities between firm-internal and external knowledge, and thereby resource and image fit between alliance partners (Teece 1986; Shah et al. 2008)?

VC managers could build their strategy considerations upon complementarities in marketing: they could consider other strategic alliances for co-promotion or co-branding (Priem 2007), thereby capturing value-creation as part of the firm's overall management strategy, in search of the best strategic fit between functional strategies and competitive strategy (Chopra et al. 2009; Besanko et al. 2009). In addition, new VC members could be chosen on the basis of complementary skill and resource sets (Shah et al. 2008; Steiner et al. 2017), on the basis of their previous success to capture value in novel ways through locally derived networks. The example of alternative food networks in Wales and the Netherlands (e.g. Marsden and Smith 2005: Graig Farm, Waddengroup Foundation) provides not only an example of complementarities in income-generating activities, for 
example embracing agri-tourism, thereby leading to 'multi-functional forms of value capture' (p. 441). Their example of such 'food networks' is also an example of Möller's (2006) "relational logic of value production", hence an example of alternative mechanisms to distribute value through network developments built on simple legal structures (logos, trademarks) to develop niche products, built upon production and marketing synergies (Mardsen et al. 2005). These synergies that are very much the result of complementarities between such network partners, benefiting from consumers' human capital for value creation (Gulati and Wang 2003; Priem 2007). Empirically, we also observe that consumers critical of established values can contribute importantly to food innovations in such networks (Lagnevik et al. 2003), highlighting the relevance of complementarities and fit between VC partners from the perspective of the customer (Shan et al. 2008: 475).

This leads to both Priem's (2007) and Möller's (2006) suggestion to rely on experts as potential value-drivers, since firms may thereby achieve a competence transfer between buyer and seller, and consequently reduce consumers' learning and thus transaction costs when the utilization of novel products requires new customer competence (Möller 2006). Beyond considering non-governmental certification agencies and management consultants as experts, a third expert category is that of knowledge transfer organizations (KTOs), which focus on producer engagement in the $\mathrm{VC}$ by stimulating the formation of knowledge platforms (Dicecca et al. 2016). Further, Dicecca et al. (2016) identify broker organizations which function in a similar way as KTOs do, yet operate mainly by forming and facilitating access to informal networks. Such transfer and broker organizations are more recently emerging across agri-food VCs in North America, labeled 'food hubs'.6

The increasing role of external experts is perhaps most striking with the more recent emphasis on sustainability certification in VCs. Evidence suggests that a variety of certifications for sustainability are required. These include sustainability of sourcing under the triple bottom line, as the example from the Italian pasta and bakery sector shows (Pancino et al. 2016), sustainability in terms of social sustainability, with regard to nutrition and poverty in general (Henson and Humphrey 2015; Anim-Somuah et al. 2013; Gómez and Ricketts 2013), and sustainability with respect to sustainable community development initiatives (Stockwell et al. 2016).

In sum, the above discussion suggests that a coordinated value-creation focus of agribusiness VCs could not only be considered in terms of fit with regard to coherence between functional and competitive strategies (Chopra et al. 2009), but also strategic fit with regard to complementarities in marketing and human capital (experts). 3.2. Evidence on value-creation and organizational design focus from well-
established value chains (beef value chains)

\footnotetext{
${ }^{6}$ Practical examples can be found from Canada (http://www1.agric.gov.ab.ca/\$Department/deptdocs.nsf/All/agdex16149), or the U.S. (http://ngfn.org/resources/food-hubs).
} 
In light of the above discussion regarding value creation, value-based marketing and Möller's (2006) 'value system continuum', this section discusses first evidence from well-established VCs in the beef sector. Value-based marketing (VBM) in North America's beef sector, sometimes termed 'grid-pricing', values animals on an individual basis, such that each animal in a sale lot receives a price that reflects its own quality attributes (Harri et al. 2009). Thus, VBM includes the application of quality discounts and premiums (carcass quality and yield grade), which go beyond a dressed weight pricing scheme, under which all animals from a given pen are typically paid the same average price (Fausti, Feuz and Wagner 1998; Riley et al. 2009; Aalhus et al. 2014). ${ }^{7}$

Although the red meat industry in North America is still dominated by average pricing of live animals in cash markets (e.g. Fausti et al. 1998; Tronstad and Unterschultz 2005), a move towards VBM began throughout the 1990's (Fausti et al. 1998), and individual carcass identification along with the development of database systems like the Beef InfoXchange System (BIXS) are now put into place, as in the case of Canada (Aalhus et al. 2014). It is somewhat striking, however, that despite an increase in consumers' real income and a shift towards consumer lifestyles which demand more value-added meat products, the meat industry has lagged in their implementation of VBM systems, as examples from North America (e.g. Fausti et al. 1998; 2013) and Africa (Soji et al. 2015; van Engelen et al. 2013) document. ${ }^{8}$ How can this apparent paradox be explained?

The observation that there are still no fully-developed fed cattle valuation systems implemented by the North American beef industry which pay price differentials for cattle varying in tenderness levels, suggests that the beef industry has continued to focus on supply-side issues as well as price and risk management issues with the goal of improving the organizational issue of supply chain coordination (Fausti et al. 1998; Harri et al. 2009; Riley et al. 2009; Fausti 2013; Aalhus et al. 2014). ${ }^{9}$ Although this focus has been expanded to pricing systems that more effectively transmit quality signals from consumers to producers (VBM), and transmit quality signals (carcass quality uncertainty) between producers and other VC members (e.g. Fausti et al. 2013), a number of intraorganizational and technological issues related to supply chain coordination seem to have been at the forefront of industry concerns. The following sections try to address six of these issues, thereby inquiring why there seems a lack of focus on use value and valuebased marketing issues. Table 1 summarizes the discussion.

\footnotetext{
${ }^{7}$ Dressed weight typically refers to the weight of an animal after eviscerating and removing the skin (hide).

${ }^{8}$ Readers interested in country-comparative reviews of beef production systems are referred to Cottle and Kahn (2014) and Kristkova et al. (2015).

${ }^{9}$ Aalhus et al. (2014) highlight that the Canadian grading system for youthful carcasses identifies both lean yield and quality attributes, yet mature carcasses are only broadly categorized. Example for cattle valuation systems that pay price differentials for growth-hormone-free beef products or other quality traits include certified Angus beef® (Siebert et al. 2013), Montana Legend Natural Angus Beef, http://www.montanalegend.com/; Montana Ranch Brand: http://www.montanaranchangus.com/; Lifeline: http://www.lifelinefarm.com/.
} 
Table 1: Key coordination issues in beef value chains

\begin{tabular}{|c|c|c|c|}
\hline & Issue & Possible ways to address issue & Key references \\
\hline 1 & $\begin{array}{l}\text { How to manage quality-related information } \\
\text { more effectively, so that price discovery } \\
\text { mechanisms do not fail? }\end{array}$ & $\begin{array}{l}\text { Increase residual control through residual } \\
\text { claimancy; cross-functional teams. }\end{array}$ & $\begin{array}{l}\text { Fausti et al. 1998; Pang et } \\
\text { al. 2015; Spanyi 2015; } \\
\text { Fousekis et al. } 2016\end{array}$ \\
\hline 2 & $\begin{array}{l}\text { How to assess and manage producers' risk } \\
\text { aversion and revenue variability as part of } \\
\text { VBM more effectively? }\end{array}$ & $\begin{array}{l}\text { Better matching between producers and particular } \\
\text { VBM contracts; analyze and control for producers } \\
\text { risk preferences and self-selection, i.e. different } \\
\text { marketing choices for different types of producers. }\end{array}$ & $\begin{array}{l}\text { Feuz, et al. 1993, 1995; } \\
\text { Anderson \& Zeuli 2001; } \\
\text { Steiner, et al. 2007, Harri } \\
\text { et al. 2009; Fausti et al. } \\
\text { 2013; Bishu et al. 2016 }\end{array}$ \\
\hline 3 & $\begin{array}{l}\text { How to integrate more objective meat quality } \\
\text { measures (carcass \& meat quality traits) and } \\
\text { control for errors in quality measurement? }\end{array}$ & $\begin{array}{l}\text { Tenderness/ palatability quality assurance schemes } \\
\text { as part of VCs, combined with technologies for } \\
\text { identifying carcass and quality traits. }\end{array}$ & $\begin{array}{l}\text { Fausti et al. 1998; Riley et } \\
\text { al. 2009; Aalhus } 2014\end{array}$ \\
\hline 4 & $\begin{array}{l}\text { How to address the issue that live weight / } \\
\text { dressed weight pricing systems are likely to } \\
\text { prevail due to reduction of pricing } \\
\text { inefficiencies for larger VCs that use average } \\
\text { pricing (as part of live weight and dressed } \\
\text { weight pricing)? }\end{array}$ & Control for market power and thin cash markets. & $\begin{array}{l}\text { Fausti et al. 1998; Gibbon } \\
\text { 2003; Gulati et al. 2005; } \\
\text { van Engelen et al. 2013; }\end{array}$ \\
\hline 5 & $\begin{array}{l}\text { How to manage complementarities in VCs } \\
\text { more effectively, (i) among organizational } \\
\text { factors, and (ii) between organizational factors } \\
\text { and functional strategies? }\end{array}$ & $\begin{array}{l}\text { Increase strategic fit through residual claimancy; } \\
\text { provide financial incentives for adopting novel } \\
\text { quality measurement and certification technologies. }\end{array}$ & $\begin{array}{l}\text { Steiner 2007; Chopra and } \\
\text { Meindl 2009; Tsai et al. } \\
\text { 2013; van Engelen et al. } \\
\text { 2013; Ding et al. } 2014\end{array}$ \\
\hline 6 & $\begin{array}{l}\text { How can inconsistencies in meat quality, } \\
\text { resulting from variability in production } \\
\text { methods, genetic diversity of animals, and } \\
\text { average pricing, be overcome as part of VBM? }\end{array}$ & $\begin{array}{l}\text { Government support to build infrastructure } \\
\text { elements: labelling \& quality-grading/ certification } \\
\text { institutions, standards harmonization, independent } \\
\text { certification \& auditing; transparency vis à vis the } \\
\text { consumer. }\end{array}$ & $\begin{array}{l}\text { Fausti et al. 1998; Riley et } \\
\text { al. 2009; Fausti et al. 2013; } \\
\text { Steiner et al. } 2014\end{array}$ \\
\hline
\end{tabular}


Considering the above six issues (Table 1), it is striking that such primarily organizational design issues of $\mathrm{VC}$ coordination appear to have dominated the attention of $\mathrm{VC}$ managers and the literature, in spite of the undisputed role of customer value for competitive advantage (Woodruff 1997) and the potential benefits of a coordinated value creation focus across VC members. Thus, while addressing this phenomenon and the above six issues in sequence, we also ask how a more effective and coordinated focus on value creation ("consumer benefit experience": Priem 2007; "value-creation logic": Möller 2006) and use value could be achieved.

Issue 1: In practice, price information reflecting an individual animal's quality attributes is often not provided to producers, or is distorted, i.e. it is rarely observed that producers receive detailed carcass information of their animals (Fausti et al. 1998; Harri et al. 2009; Aalhus 2014). ${ }^{10}$ A first answer to the issue of how to manage quality-related information more effectively, could be to increase residual control (rights), hence control also in uncontracted-for situations, through residual claimancy. Considering that VBM contracts are, by their nature, incomplete contracts, one solution to the lack of information provision could be to make the extent of information provision (feedback of slaughter information to producers) a function of the extent of asset ownership (Hart 1995): producers who have made a greater investment in a VC (e.g. they retain ownership of cattle, contribute a larger number of animals, or make relation-specific investments) could be granted greater access to price and quality information of their own and possibly other animals in the $\mathrm{VC}$, for internal and external benchmarking purposes. This information could be exchanged in real time electronically (Pang et al. 2015), building upon the early information exchange initiatives in red meat VCs in North America. ${ }^{11} \mathrm{~A}$ second answer to this information management problem could be a reference to an old solution: create and implement cross-functional teams in VCs, an idea introduced in the 1990's by MIT's Michael Hammer (Rosemann et al. 2015; Spanyi 2015), which is essentially another way to spread residual control rights by allocating ownership across functions in a VC. ${ }^{12}$ The limited historical adoption of residual claimancy, real-time electronic data exchange and multi-functional teams in VCs may have to do with asymmetric distribution of and access to information across chain members (Fousekis et al. 2016). Such asymmetry is more easily sustained when market power is asymmetric (Azzam 1997), possibly explaining why managerial focus has been on organizational design issues in seeking to improve a value chain's performance.

\footnotetext{
${ }^{10}$ It is equally rare in other agri-food businesses to receive and use similar information that is closer to the end of the value chains, such as wholesale-based attributes, as the example of the wine industry demonstrates with respect to bottle-price-based contracts (Steiner 2012).

11 An early example from Canada, where this has been put into practice, is Carmen Creek: http://www.carmencreek.com/. Consider a similar example from the UK of real-time information exchange, where "Costs were managed cooperatively with suppliers [of Sainsbury] by integrating cost data across the supply chain" (Dekker 2003: 21).

${ }_{12}$ Strictly speaking, this would imply the allocation of legal ownership of assets (Hart 1995) across functional teams, which we would not always expect in practice, given the transaction costs involved. Yet thinking of intellectual property issues (leakage) in value chains could be an example to rationalize welldefined legal ownership allocated in cross-functional teams.
} 
Issue 2: Much of the literature has also focused on managing economic risk in VBM of fed cattle (Feuz, et al. 1993, 1995; Fausti, et al. 1998; Harri et al. 2009; Fausti et al. 2013). As VCs move towards VBM, a key question is thus, how to manage the increasing per-head and per-pen revenue-variability that has been found to go along with this move (Fausti et al. 1998; Anderson et al. 2001; Steiner, et al. 2007; Harri et al. 2009), in order to overcome potential reluctance of producers to adopt VBM. ${ }^{13}$ It is striking that the majority of empirical evidence suggests that price risk associated with VBM pricing is difficult to manage effectively, particularly with existing futures instruments (Steiner, Unterschultz and Goddard 2007; Harri et al. 2009; Steiner et al. 2014). When beef producers have the option to choose from different VBM contracts (different price grids, or choose between grid pricing and a dressed weight system), their self-selection into those contracts is likely to be, at least in part, a reflection of their differences in risk aversion. Therefore, the varying levels of producer efforts (including levels of adoption of risk-management tools such as futures) and outputs (beef quality traits) are not only the result of a variation in the intensity of contractual incentives (level and composition of grid prices), but also a function of selection in accordance with producers' degree of risk aversion. In order to better understand the relationship between value-creation and contractual incentives in beef VCs, a better control of individual producer's risk preferences and the matching between producers and particular VBM contracts is thus desirable in alliance relationships (Steiner et al. 2014). Further, controlling for producers' self-selection (i.e., analyzing different marketing choices of different types of producers over time) could be regarded as a step towards managing producers' risk aversion more effectively, if for example, this selection information related to different types of VBM (grid pricing systems that differ in their quality attributes) could be used by those VC members who are designing the price grid (e.g., a board representing the interests of all firms in a VC). This more fine-tuned approach based on value-based marketing and differences in producers' risk aversion may also lead to efficiency gains for all VC members, since lower risk premiums are likely required to satisfy the opportunity costs (participation constraint) of producers. On the other hand, increasing transaction costs with an increasing proliferation of different types of (VBM) contracts (Oxley 1997) would seem to suggest that the number of such value-based marketing channels remains constrained. Interestingly in this context, Fausti et al. (2013) observe that risk and producer risk preferences provide the linkage between carcass quality uncertainty and producer marketing decisions, and contribute toward explaining why we observe the coexistence of multiple marketing channels in North America - once again, highlighting an organizational phenomenon.

Issue 3: North American beef producers appear to continue to distrust packers and retailers (e.g. Steiner et al. 2007; Belk et al. 2014), since producers have frequently to rely on pricing systems that are associated with subjective quality assessments, such as human grading of carcasses (Fausti et al. 1998). Consequently, an integration of more objective quality measures (such as shear force as a proxy for tenderness) into pricing contracts could contribute toward the performance of entire value-chains. Australia has

13 “... a producer selling similar groups of slaughter cattle would experience decreased revenue and increased revenue variability under the grid pricing system relative to the dressed weight price system." (Fausti et al. 1998: 84) 
implemented a so-called 'palatability assurance' scheme (Carriquiry 2004), which has also been explored theoretically in terms of a 'tenderness-augmented price grid' with US beef data (Riley et al. 2009). ${ }^{14}$ Technology has now advanced such that, in practice, it is possible to identify a number of carcass and meat quality traits through grade cameras, dual energy X-ray absorptiometry and spectroscopic methods (Aalhus et al. 2014), or reduce meat safety hazards and increase productivity through the adoption of Augmented Reality in VCs (Christensen et al. 2016). The integration of such information and the continuous process monitoring capabilities through Internet of Things (IoT) platforms could be expected to further reduce distrust and thus transaction costs of collaborating, thereby contributing toward the quality of decision-making in VCs and toward valuebased marketing. Thus, there may be a technology adoption explanation for the past emphasis on organizational design issues relative to a value-based marketing focus.

Issue 4: With an increase in the scale of a beef processing operation, average pricing as part of live weight and dressed weight pricing is likely more acceptable and thus more prevalent since quality estimation errors (differences between expected quality ex-ante mortem and actual quality ex-post mortem) are more likely to be normally distributed, hence quality estimation errors have a greater negative impact on price discovery in small scale VCs. Consequently, if the sector becomes increasingly consolidated, we could expect that there continue to be disincentives for the adoption of VBM, and instead a managerial focus on organizational design issues to drive $\mathrm{VC}$ performance. As a result of the typically higher costs for small-scale beef operations to bear risks, we could indeed expect a continuing pressure toward vertical integration of small-scale operations (Hennessy 1996). This trend toward continued vertical integration may also lead to increasing market power asymmetries and thin cash markets, thereby potentially reducing the functionality of VBM. VC projects have thus tried to provide incentives to smallerscale value chains to grow and strengthen farmer groups (van Engelen et al. 2013). In sum, information asymmetries as well as a tendency towards thin markets and thus lack of information transmission may thus contribute further to explaining a primary focus on organizational design issues to drive VC performance.

Issue 5: Managing complementarities between organizational factors (Milgrom and Roberts 1995), such as between performance evaluation systems like VBM and the relationship of those systems to the degree of decentralization (in terms of ownership versus control), and managing complementarities between organizational factors and functional strategies in VCs more effectively, is likely to remain an issue in practice. One reason is that VBM represents only one component in the set of potentially complementary incentives that VC members could employ (Steiner 2007). ${ }^{15}$ Further, we could anticipate that in a dynamic competitive environment, VCs are constantly trying to maintain consistency, create and sustain strategic fit between individual functional strategies, and align their overall chain strategy with consumer needs (Chopra and Meindl

\footnotetext{
${ }^{14}$ We have evidence that shear force and tenderness are closely related (the correlation between shear force and consumer rated tenderness was found to be -0.76: Wulf et al. 1997). See Tronstad and Unterschultz (2005) for a discussion of the Ralphs-Sunland Beef alliance, which was built upon a tenderness scheme.

${ }^{15}$ Activities are considered complements if doing more of any one of them increases the returns to doing more of the others (Milgrom and Roberts 1995).
} 
2009). The ability of managers to achieve strategic fit, and to extract rents from the emerging synergies, continues therefore likely to be a key component of successful chain management, especially when we consider observed alignment issues relating to the lack of fit of pricing and risk-management strategies between members in beef VCs (Steiner et al. 2007). Extracting such rents, however, likely requires more extensive information collection and exchange between firms and a corresponding increase in the use of residual control and thus residual claimancy (Hart 1995; Steiner 2012). More specifically, the benefit of a more extensive information exchange (IoT, RFID) would be that price incentives likely work more effectively to create value, by linking the extent of asset ownership, as part of the VBM contracts and the use of quality measurement technology (monitoring), with the price incentives of the grid. ${ }^{16}$ However, the fact that we still observe limited information sharing in practice (e.g., Bott 2010; Aalhus et al. 2014) suggests that on top of transaction cost explanations that could be brought forward against managing complex complementarities, a lack of trust between VC members continues to be significant (Ding et al. 2014), hampering therefore a further implementation of VBM. This could, once more, contribute toward explaining the past emphasis on organizational design issues relative to a value-based marketing focus, in aiming to drive $\mathrm{VC}$ performance.

As an addendum to issue 5, and noting the above emphasis on information technology, the question remains as to the role of government for improving strategic fit (managing complementarities). First we note that when there are issues around information asymmetries in the context of potential systemic risks (Hennessy et al. 2003) related to credence attributes and food safety in agri-business VCs (e.g., BSE, E. Coli), there could be scope for government intervention. ${ }^{17}$ Aside from providing an effective institutional framework (e.g. Steiner 2006), one further mechanism through which the government could provide support includes the use of incentives for adopting novel quality measurement and certification technologies that help to reduce information asymmetries and market failure, and contribute to enhancing consumer trust in beef products. Most obvious are financial incentives provided by a government, for example for information technology adoption in VCs (e.g. Tsai et al. 2013). Yet social incentives that are generated through farmer groups (van Engelen et al. 2013), as well as social incentives embedded in local networks, may also be relevant, since these incentives can ultimately impact VC performance (Adler and Kwon 2002; Stam et al. 2014; Steiner et al. 2016). ${ }^{18}$

\footnotetext{
16 As Menard (2004) emphasizes, it is important that the choice of governance structures (e.g. the type of monitoring, procedures for regulating re-negotiations and the process of selecting partners) adequately complements contracts and contribute to their implementation.

17 Numerous examples could be provided with regard to credence attributes: Steiner and Yang (2010) for the case of BSE labelling; Steiner, Gao and Unterschultz (2010) for the case of GMO labelling; Grebitus et al. (2015) for the case of footprint labelling.

18 Smaller-scale value chains may be using local and social embeddedness as the basis for informal mechanisms of coordination (Bloom and Hinrichs 2016; Gulati and Wang 2003), promoting 'fair' production and marketing standards (social sustainability) to ensure fair returns to producers (Soji et al. 2015), and obtaining high consumers' valuation for distinct regional origin products (Steiner et al. 2010) and environmental sustainability standards linked to their value chain.
} 
Issue 6: Empirical evidence, mostly from North America, suggests that because VBM is rejected by beef VC members, quality inconsistencies continue to persist (Fausti et al. 1998; Riley et al. 2009; Steiner et al. 2014). ${ }^{19}$ As long as these quality inconsistencies can be linked to asymmetric or incomplete information linked to market failure, public support could be justified, as noted above (issue 5). However, the imminent challenge for public policymakers is to support a flexible, value-based-driven supply chain strategy, by supporting appropriate infrastructure elements that are also transparent to consumers (e.g. labelling for BSE testing: Steiner \& Yang 2010; quality-grading institutions driven by consumer research: Bott 2010; Polkinghorne 2008, 2015), and by supporting standards harmonization, independent certification and auditing that likely enhances the adoption of VBM-type systems in the medium and long run. ${ }^{20}$ Yet, evidence from Australia suggests that a consumer-focused, tenderness-based certification scheme - Meat Standards Australia - has had little catalytic effect of moving VCs toward a greater level of coordination (Bott 2010). In particular, and with regard to the extent and role of collaboration, Bott (2010) finds that the implementation of the Meat Standards Australia grading system does not appear to have an effect on moving toward more integrated decision-making. Therefore, the observed lack of coordination, integrated decisionmaking and standards harmonization contributes further toward the observation of continuing quality inconsistencies and thus a lack of successful value-based marketing. Once more, a lack of trust and the asymmetric distribution of information and market power between VC members are therefore likely explanatory factors for the interest of policymakers and managers to focus on organizational issues in their strife to improve VC performance.

In sum, the above discussion of six factors has tried to capture, document and conceptualize the proposed phenomenon, thereby determining its scope, prevalence and context (Schwarz et al. 2016; van de Ven 2016). The discussion suggests that beef production systems and VCs continue to suffer from failures to produce quality meats that are most desired by consumers. Outdated, yet long established grading systems, the asymmetric distribution of information and gains from value-based marketing between VC members, and a lack of trust and lack of allocation of residual control rights among industry participants appear to be key issues in the way of coordinated value creation. As such, they present unique opportunities for beef VCs, perhaps especially those that are willing to take up opportunities provided by novel technologies and shared IoT ecosystems for optimizing information flows. ${ }^{21}$

\footnotetext{
${ }^{19}$ Soji et al. (2015) provide evidence from South Africa that the lack of acceptance of VBM and related meat classification measures can also originate from externalities that the formal classification of meat carcasses imposes on the informal sector.

20 The role of standards (non-GM private standards) and the necessary changes in value chain governance structures have also been highlighted in the context of the poultry industry (Passouello et al. 2015).

21 Value chains face increasing pressure to adjust to international standards (Dannenberg et al. 2013) and procurement practices of larger retail types, which is likely to be more difficult for small-scale value chains due to higher transaction costs (Cook 2002). However, we could expect that the scale disadvantages of smaller value chains continue to diminish over time as transaction costs will likely continue to fall with the increasing adoption of novel technologies relevant for the connectedness of value chain members (RFID, and IoT: Costa et al. 2013; Mainetti et al. 2013; Verdouw et al. 2013; Dandage et al. 2017).
} 


\subsection{Evidence on value-creation and organizational design focus from emerging value chains (medicinal, aromatic plants and non-timber forest products)}

Following a surge in domestic and international demand for medicinal and aromatic plants (MAP) in the 1990's (Rao et al. 2004; Lange 2002), analysts have suggested that the rapid depletion of natural MAP requires emerging VCs to focus on sustainable harvesting practices, certification for good resource management and 'equitable biopartnerships' (Singh 2005; Bhattacharya et al. 2008; Bhattacharyya et al. 2009; Choudhary et al. 2014). Yet to implement such VCs, has there been a predominant focus of policymakers and analysts on organizational design issues, relative to a weak attention on coordinated value creation; and if so, what would explain such a focus? Table 2 summarizes the key issues and the discussion that follows. 
Table 2: Key coordination issues in emerging value chains (medicinal \& aromatic plants, non-timber forest products)

\begin{tabular}{|l|l|l|l|}
\hline & Issue & Possible ways to address issue & Key references \\
\hline 1 & $\begin{array}{l}\text { Rapid depletion of the resource base } \\
\text { associated with unsustainable VC } \\
\text { management practices. }\end{array}$ & $\begin{array}{l}\text { More coherent legal and policy framework; } \\
\text { enforcement mechanisms that force organizations to } \\
\text { adhere to sustainability standards. }\end{array}$ & $\begin{array}{l}\text { Lange 2002; Rao et al. 2004; } \\
\text { Bhattacharya et al. 2008; } \\
\text { Mishra et al. 2013; Choudhary } \\
\text { et al. 2014; Tieguhong et al. } \\
\text { 2015; Dandage et al. 2017 }\end{array}$ \\
\hline 2 & $\begin{array}{l}\text { Information asymmetry between VC } \\
\text { members, related to market power issues }\end{array}$ & $\begin{array}{l}\text { Regulation; transparency; reduce transaction costs; } \\
\text { retain use value and transforming credence attributes } \\
\text { through labeling and certification }\end{array}$ & $\begin{array}{l}\text { Caswell et al. 1996; Lange } \\
2002 ; \text { Kepe 2007 }\end{array}$ \\
\hline 3 & $\begin{array}{l}\text { Lack of effective marketing strategy; } \\
\text { lack of access to marketing institutions } \\
\text { and governance mechanisms }\end{array}$ & $\begin{array}{l}\text { Access to information technology (e.g. RFID) and } \\
\text { market data; substitute missing marketing institutions } \\
\text { and governance mechanisms through growing local } \\
\text { social capital (Fig. 1) }\end{array}$ & $\begin{array}{l}\text { Jensen 2009; Biersum et al. 2013 } \\
\text { Wourdieu 1986, }\end{array}$ \\
\hline 4 & $\begin{array}{l}\text { Lack of inter-firm linkages for VC } \\
\text { growth. }\end{array}$ & $\begin{array}{l}\text { Organizing producers into interest groups; } \\
\text { relationship development; develop trust, network size } \\
\text { and social capital. }\end{array}$ & $\begin{array}{l}\text { Inkpen and Tiersum et al. 2014; Hastings } \\
\text { et al. 206 }\end{array}$ \\
\hline 5 & Lack of leadership in VCs. & Support leadership through 'value chain captain'. & Willem te Velde et al. 2006 \\
\hline
\end{tabular}


When we consider one of the world's leading player in the MAP market, India, we observe that MAP policies (e.g. subsistence use rights) differ widely across states, and that a coherent legal and policy framework is lacking (Bhattacharya et al. 2008; Mishra et al. 2013; Dandage et al. 2017). So as to support the growth of viable VCs, policy makers are therefore likely challenged to first level out the regulatory playing-field (Choudhary et al. 2013), and then implement a coherent use rights and certification scheme as a basis for effective resource management practices relevant to VCs. Because drug manufacturers and exporters are major consumers of wild MAP (Bhattacharya et al. 2008) and incentives for violating sustainable management practices are high in the face of large demand for MAP, it is unlikely sufficient to rely on domestic government initiatives that "encourage" manufacturers and exporters to "use certified raw materials which may lead to a reputation for good resource management.", as Bhattacharya et al. (2008: 43) suggest. Strict and transparent certification and quality control regulations are needed (see Lange 2002, for evidence from China), yet to be followed up by corresponding enforcement mechanisms (fines, liability, use of technology) to bring manufacturers and exporters to adhere to appropriate standards that are currently judged inappropriate (Choudhary et al. 2014). So, although an emphasis on retaining use value and transforming credence attributes (Caswell et al. 1996) into search attributes through labeling and certification would likely benefit the entire MAP VC, such efforts would benefit from being complemented by an institutional coherent framework that provides firms and local VCs the legal security and planning horizon to focus on value-generating efforts. Yet in the absence of such a framework, it appears that entrenched information and market power asymmetry between VC members (see above evidence on exporters and manufacturers) are providing incentives to retain an institutional status quo. In this context, it could be expected to observe that issues are addressed in declining order of contestability, starting with most abstract levels from an individual stakeholder's perspective: overall legal and policy framework issues, then organizational design issues as they apply to the VC structure (e.g. 'equitable bio-partnerships'), then specific valuecreation issues.

Similar to the evidence discussed for beef VCs, MAP value chains aiming for a renewed focus on value-creation could provide producers with access to information technology (e.g. RFID) and market (consumer) data, thereby enabling them to reduce transaction costs, overcome monopolizing traders and access new markets. ${ }^{22}$ Yet evidence on such efforts is scant. Evidence from pilot projects with MAP in India suggests that an incremental approach towards value creation and VC growth is needed and sometimes practiced. Bhattacharya et al. (2008) recommends an incremental approach in terms of allowing market participants to go through a phased adoption of good management practices (phased over time, as well as in terms of distinct producer groups), thus allowing VC members to adapt to the required documentation and certification needs. Given the diversity of farmers in India and in similar economies, Singh (2005) also

\footnotetext{
22 Issues of power and wealth inequity seem to be rampant, both in India (Choudhary et al. 2014; Bhattacharya et al. 2008) and elsewhere. Bhattacharya et al. (2008, p.38) suggest that "At present, pricing is mostly controlled by traders with no regard for benefit sharing.". Similarly, Kepe (2007, p.181) suggests for MAP in South Africa that "Wealthier, urban-based entrepreneurs, including some traditional healers, who have better access to cash, facilities and clients, appear to benefit the most.".
} 
suggest that a structured approach towards value-chain growth - by organizing producers into small farmer interest groups (10 to 15) with similar social and economic backgrounds and similar objectives - is a key factor for successful growth of MAP VCs. Further, Singh (2005) used group leaders of established MAP to grow the VCs by engaging these leaders in 'exposure visits' with other established farmer groups that were experimenting with new MAP, and by sending the group leaders as 'trainers' to newly formed farmer groups. The success of these initiatives underlines the importance of leadership, trust and a relational view (Lavie 2006) for growing VCs. Insights from Hastings et al.'s (2016) expert panel analysis, and from the forest products industry literature reviewed by Piltan et al. (2014) also support this role of creating value through such relationship development efforts.

A number of examples from non-timber forest product (NTFP) VCs offer further insights that reinforce those derived from the above MAP VCs. Wiersum et al. (2013) highlight the overall diversity and coexistence of formal and informal institutions, which typically characterize NTFP governance and drive decision-making in production and marketing. As in the context of MAP, these can be accountable institutions that help to reduce transaction costs, contribute to balanced power relationships and sustainable value creation in NTFP VCs. Yet consider the significant challenge due to such transaction costs, for example in terms of corruption that accounted for an average of 34\% of trader's costs, corresponding to $81 \%$ of recorded financial transactions, of Cameroon's NTFP's value chain in 2010 (Tieguhong et al. 2015). Despite such challenges, there is evidence that triple bottom line performance aspects have been achieved: In a study on NTFPs from the Lao People's Democratic Republic, Jensen (2009) documents that local VCs based on agarwood were able to generate cash income to local communities while simultaneously creating incentives for conservation of trees and forested ecosystems. Several of these conflicting aspects of income generation and thus poverty alleviation versus contributing to biodiversity and suppressing corruption have also been highlighted for NTFP VCs in Cameroon (Tieguhong et al. 2015). Yet this evidence highlights the preoccupation with issues related formal and informal institutions, rather than valuebased marketing issues.

A second example from emerging NTFP (palm products and mushrooms) VCs in Bolivia and Mexico (Willem te Velde et al. 2006) supports another key component which seems to have led to successful VCs in the case of India: the role of leadership as part of a VC's governance structure. Willem te Velde et al. (2006) suggest that this leadership derives from an 'entrepreneurial value-chain captain' who acts as driver for spreading successful commercialization through NTFP VCs. Thus, without this leadership (and thus governance and organizational) component, the mere focus on value-based marketing is unlikely to have ensured successful VCs. However, what could also be learned from developed economies is that such a shift in value-chain governance (leadership) from, for example, food manufacturer to retailers, can be controversial as it raises again power and equity issues for other stakeholders in the VC (Burch and Lawrence 2005).

The above evidence from emerging MAP and NTFP VCs may be taken to highlight further aspects relating to organizational design that have been discussed in the literature 
at VC and sectoral level (e.g. Nelson 1994; Fukuyama 2001; Wiersum et al. 2014): the role of informal governance (leadership) and trustworthiness (Cook \& Schilke 2010), and thus the role of social capital and the underlying norms of behaviour (Inkpen and Tsang 2005; Wiersum et al. 2014), is of interest to VCs as these institutionalized relationships can act as substitutes to formal public institutions (Wiersum et al. 2014 refer to the coexistence of formal and informal institutions) while formal and informal institutions may act as complements to physical infrastructure needs in driving emerging VCs performance (Figure 1).

\section{Figure 1: Relationships between institutions and infrastructure in value chains}

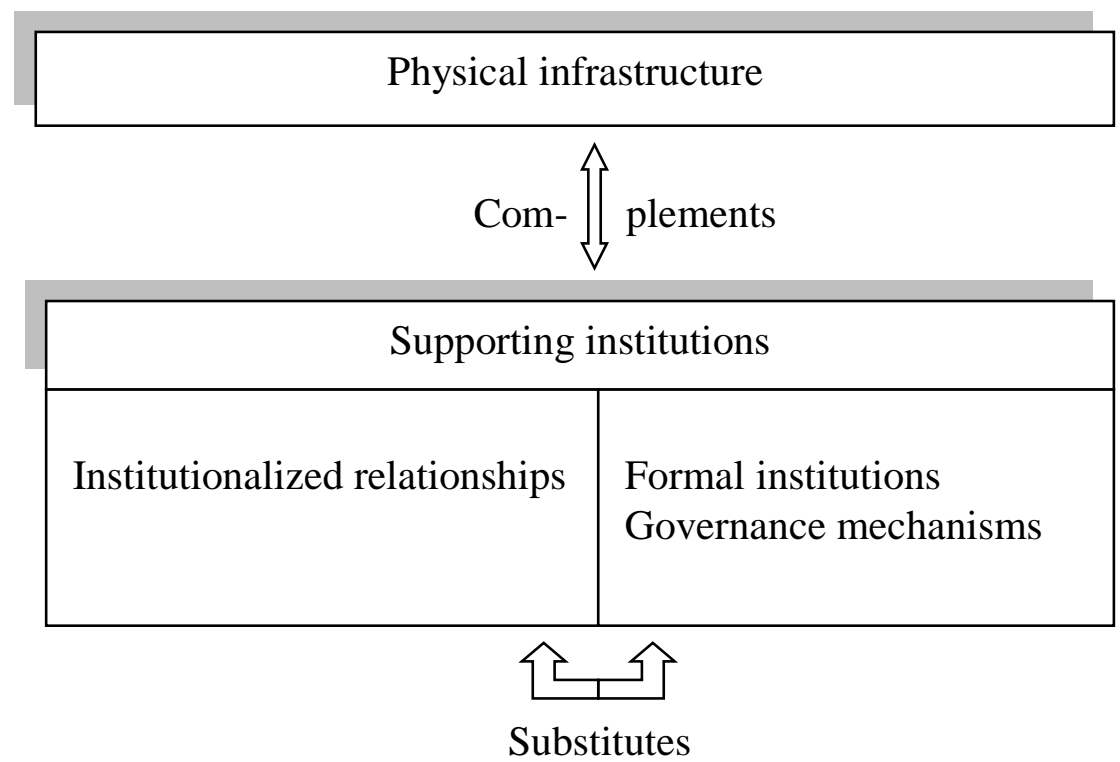

Source: own

In the case of MAP and NTFP VCs, institutionalized relationships could also become valuable substitutes (Fig. 1) to governance mechanisms (labelling, certification, auditing) that are frequently absent where these VCs operate, yet they are typically needed in such emerging VCs, since a coordinated effort of such institutional polycentrism of rulesetting centers (Ostrom 2010) bears significant performance potentials for emerging VCs

\section{Conclusions and discussion}

This paper attempts to draw on empirical evidence from agri-business value chains (VCs) to highlight and distill an apparent phenomenon, the pre-occupation of the literature with organizational design issues, rather than with customer value creation. To explore this phenomenon, well-established VCs and production systems from the beef sector are contrasted with emerging VCs from the medicinal and aromatic plants (MAP), and nontimber forest products (NTFP) sectors. While accounting for issues related to value-based marketing, strategic fit, technology adoption, and enabling formal and informal institutions, the evidence suggests that a coordinated value creation focus in beef VCs is 
judged not to have been implemented effectively, while organizational design issues seem to dominate the literature and industry efforts. Reasons for this lack of coordinated value creation focus include an asymmetric distribution of gains across beef VCs of different scale, outdated grading systems, the lack of use of residual claimancy, the uneven distribution of information and market power, and a lack of trust among industry participants. The evidence from MAP and NTFP sectors suggests that the absence or the lack of access to marketing institutions, as well as entrenched asymmetric market power structures, can frequently be made responsible for the lack of focus on value creation across the VCs, pushing instead stakeholders to focus on governance and thus organizational design issues, in an effort to improve VC performance.

A number of policy and managerial implications could be identified. First, physical infrastructure issues (i.e. production or marketing), and issues related to formal and informal institutions impeding VCs are often addressed in isolation. Yet when infrastructure and institutions act as complements, benefits can accrue in terms of higher VC performance. Further, in those business environments where formal institutions are missing, institutionalized relationships provided through VCs (social capital) can act as substitutes for formal institutions. This basic insight could help to support coordinated value-creation efforts in cases where physical production and marketing infrastructure is present, yet formal institutions are lacking. Second, in the presence of systemic risks, thin markets and the asymmetric distribution of and access to information, policymakers can play an important role in developing the value-creation focus of VCs, most obviously through formal governance mechanisms (labelling, certification, auditing), and the strengthening of absorptive capacity between VC members. Considering a global review of productive strategies to support small producers as part of VCs in rural development (Farrington \& Mitchell 2006), our conclusions resonate with those from Farrington et al. (2006), as they suggest that market facilitation (in terms of supporting producers to counter market failures that constrain their current engagement with global market processes), direct support to small producers (e.g., use of collective action to strengthen the bargaining position of small producers), and enhancing economic infrastructure (incl. communications systems) could be priority areas to support the successful engagement of VC stakeholders, thereby moving toward a greater value creation focus.

Considering the large literature on $\mathrm{VCs}$, a natural limitation of this short paper applies to the selective empirical evidence from a subset of sectors (beef, MOP, NTFP), used to contrast emerging from well-established VCs, to better ground the phenomenon put forward. In spite of this limitation, the evidence presented also suggests that the overall key benefits of promoting VCs with a strong value-creation focus rests with their potential role as catalyst for local entrepreneurship and income growth, while accounting for emerging sustainability demands from consumers. Considering these potential benefits, more comparative empirical research is needed on agri-business VCs with an emphasis on improving our understanding of organizational design and value-creation issues. 


\section{References}

Aalhus, J. L., López-Campos, Ó., Prieto, N., Rodas-González, A., Dugan, M. E., Uttaro, B., \& Juárez, M. (2014). Review: Canadian beef grading-Opportunities to identify carcass and meat quality traits valued by consumers. Canadian Journal of Animal Science, 94(4), 545-556. http://dx.doi.org/10.1139/CJAS-2014-038

Adler, P.S. and Kown, S. (2002). Social Capital: Prospects for a New Concept, Academy of Management Review, 27(1): 17-40. doi: 10.5465/AMR.2002.5922314

Ali, J. and S. Kumar (2011) Information and communication technologies (ICTs) and farmers' decision-making across the agricultural supply chain, International Journal of Information Management, 31(2), 149-159. http://dx.doi.org/10.1016/j.ijinfomgt.2010.07.008

Anastasiadis, F., \& van Dam, Y. (2014). Consumer driven supply chains: the case of Dutch organic tomato. Agricultural Engineering International: CIGR Journal, 1120.

Anim-Somuah, H., Henson, S., Humphrey, J., \& Robinson, E. (2013). Strengthening agri-food value chains for nutrition: Mapping value chains for nutrient-dense foods in Ghana (No. Evidence Report; 2). Institute of Development Studies (IDS), Sussex.

Azzam, A. M. (1997). Measuring Market Power and Cost-efficiency Effects of Industrial Concentration. Journal of Industrial Economics, 45(4): 377-386. DOI: 10.1111/1467-6451.00054

Bahlmann, J., Spiller, A. (2009): Inter-organizational information systems in meat chains: the linkage between supply chain organization and system requirements, Journal

on Chain and Network Science 9 (1), S. 59-69.

http://dx.doi.org/10.3920/JCNS2009.x159

Barney, J. (1991) Firm resources and sustained competitive advantage, Journal of Management, 17: 99-120. DOI: https://doi.org/10.1177/014920639101700108

Belk, K. E., Woerner, D. R., Delmore, R. J., Tatum, J. D., Yang, H., \& Sofos, J. N. (2014). The meat industry: Do we think and behave globally or locally?. Meat Science, 98(3), 556-560. http://dx.doi.org/10.1016/j.meatsci.2014.05.023

Besanko, D., Dranove, D., Shanley, M. and S. Schaefer (2009) Economics of Strategy, John Wiley \& Sons, $5^{\text {th }}$ Edition, New York.

Bhattacharya, P., Prasad, R., Bhattarchayya, R. and A. Asokan (2008) Towards certification of wild medicinal and aromatic plants in four Indian states, Unasylva 230(59): 35-44.

Bhattacharyya, R., Asokan, A., Bhattacharya, P. and R. Prasad (2009) The potential of certification for conservation and management of wild MAP resources,

9653-Z

Biodiversity and Conservation, 18(13): 3441-3451. DOI: 10.1007/s10531-009-

Bishu, K. G., O’Reilly, S., Lahiff, E., \& Steiner, B. (2016). Cattle farmers’ perceptions of risk and risk management strategies: evidence from Northern Ethiopia. Journal of Risk Research, 1-20. http://dx.doi.org/10.1080/13669877.2016.1223163

Bloom, J. D., \& Hinrichs, C. C. (2016). Informal and formal mechanisms of coordination in hybrid food value chains. Journal of Agriculture, Food Systems, and 
Community Development, $\quad 1(4), \quad 143-156 . \quad$ DOI:

http://dx.doi.org/10.5304/jafscd.2011.014.016

Bott, G. (2010) The Effects of a Quality Grading System on the Development of Consumer Driven Best Practice Value Chains: The Example of Meat Standards Australia, MSc Thesis, Dept. of Rural Economy, University of Alberta, 226 p.

Bourdieu, P. (1986) The forms of capital, in: J. G. Richardson (ed.), Handbook of theory and research for the sociology of education, 241-258. New York: Greenwood.

Bowman, C. and Ambrosini, V. (2000) Value creation versus value capture: Towards a coherent definition of value in strategy, British Journal of Management, 11: 1-15.

DOI: $10.1111 / 1467-8551.00147$

Bryceson, K. and G. Slaughter (2010) Alignment of performance metrics in a multienterprise agribusiness: Achieving integrated autonomy?, International Journal of Productivity and Performance Management, 59(4): 325-350.

http://dx.doi.org/10.1108/17410401011038892

Burch, D., and G. Lawrence. (2005). Supermarket own brands, supply chains, and the transformation of the agri-food system. International Journal of Sociology of Agriculture and Food 13(1): 1-18.

Carriquiry, M. (2004) Guaranteed Tender Beef: Opportunities and Challenges for a Differentiated Agricultural Product, Working Paper 04-WP 371, Center for Agricultural and Rural Development, Iowa State University, Ames, Iowa.

Caswell, J. A., \& Mojduszka, E. M. (1996). Using informational labeling to influence the market for quality in food products. American Journal of Agricultural Economics, 78(5): 1248-1253.

Chopra, S. and P. Meindl (2009) Supply Chain Management: Strategy, Planning, and Operation, $4^{\text {th }}$ ed., Pearson Education.

Choudhary, D., Kala, S. P., Todaria, N. P., Rawat, R. B. S., Kunwar, M. S., \& Kollmair, M. (2013). Upgrading mountain people in medicinal and aromatic plants value chains: lessons for sustainable management and income generation from Uttarakhand, India. International Journal of Sustainable Development \& World Ecology, 20(1), 45-53. http://dx.doi.org/10.1080/13504509.2012.738434

Choudhary, D., Kala, S. P., Todaria, N. P., Dasgupta, S., \& Kollmair, M. (2014). Drivers of Exploitation and Inequity in Non-Timber Forest Products (NTFP) Value Chains: The Case of Indian Bay Leaf in Nepal and India. Development Policy Review, 32(1), 71-87.

Christensen, L. B., \& Engell-Nørregård, M. P. (2016). Augmented reality in the slaughterhouse-a future operation facility?. Cogent Food \& Agriculture, 2(1): 1188678. http://dx.doi.org/10.1080/23311932.2016.1188678

Christopher, M. and J. Gattorna (2005) Supply chain cost management and value-based pricing, Industrial Marketing Management, 34(2): 115-121. http://dx.doi.org/10.1016/j.indmarman.2004.07.016

Cohen, W. M., \& Levinthal, D. A. (1990). Absorptive capacity: a new perspective on learning and innovation. Administrative science quarterly, 128-152.

Cook, R. (2002) The U.S. Fresh Produce Industry: An Industry in Transition, in: Postharvest Technology of Horticultural Crops, $3^{\text {rd }}$ ed., Kader, A. (ed.) Univ. of California, Agriculture \& Natural Resources Publication 3311, 2: 5-30. 
Cook, K. S., \& Schilke, O. (2010). The role of public, relational and organizational trust in economic affairs. Corporate Reputation Review, 13(2): 98-109.

doi:10.1057/crr.2010.14

Coronado, J., Bijman, J., Omta, O. and O. Lansink (2010) Relationship characteristics and performance in fresh produce supply chains: the case of the Mexican avocado industry, Journal on Chain and Network Science, 10(1): 1-15.

Costa, C., Antonucci, F., Pallottino, F., Aguzzi, J., Sarriá, D., \& Menesatti, P. (2013). A review on agri-food supply chain traceability by means of RFID technology. Food and Bioprocess Technology, 6(2): 353-366. doi:10.1007/s11947-012-0958-7

Cottle, D. and L. Kahn (2014). Beef Cattle Production and Trade, CSIRO Publishing, Collingwood, Australia,

Dandage, K., Badia-Melis, R., \& Ruiz-García, L. (2017). Indian perspective in food traceability: A review. Food Control, 71, 217-227. http://dx.doi.org/10.1016/j.foodcont.2016.07.005

Dannenberg, P., \& Nduru, G. M. (2013). Practices in international value chains: The case of the Kenyan fruit and vegetable chain beyond the exclusion debate. Tijdschrift voor economische en sociale geografie, 104(1), 41-56. DOI: 10.1111/j.14679663.2012.00719.x

Davidow, W. and Malone, M. (1992). The Virtual Corporation: Structuring and Revitalizing the Corporation for the 21st Century, Harper Collins: New York.

Dekker, H. (2003) Value chain analysis in interfirm relationships: a field study, Management Accounting Research, 14: 1-23. http://dx.doi.org/10.1016/S1044-5005(02)00067-7

Dicecca, R., Pascucci, S., \& Contò, F. (2016). Understanding reconfiguration pathways of agri-food value chains for smallholder farmers. British Food Journal, 118(8), 1857-1882. http://dx.doi.org/10.1108/BFJ-05-2016-0194

Ding, M.J., Jie, F., A. Parton, K., \& J. Matanda, M. (2014). Relationships between quality of information sharing and supply chain food quality in the Australian beef processing industry. The International Journal of Logistics Management, 25(1), 85-108. http://dx.doi.org/10.1108/IJLM-07-2012-0057

Eisenhardt, K.M., and Graebner, M.E. (2007) Theory building from cases: opportunities and challenges. Academy of Management Journal 50 (1), 25-32.

Farrington, J. and J. Mitchell (2006) How can the rural poor participate in global economic processes? Natural Resource Perspectives 103: 1-6, Overseas Development Institute, ODI.

Fausti, S., Feuz, D. and J. Wagner (1998) Value-based marketing for fed cattle: A discussion of the issues. International Food and Agribusiness Management Review 1(1): 73-90. http://dx.doi.org/10.1016/S1096-7508(99)80029-9

Fausti, S. W., Wang, Z., \& Lange, B. (2013). Expected Utility, Risk, and Marketing Behavior: Theory and Evidence from the Fed Cattle Market. Canadian Journal of Agricultural Economics, 61(3), 371-395. DOI: 10.1111/j.1744-7976.2012.01261.x

Fearne, A., Garcia Martinez, M., \& Dent, B. (2012). Dimensions of sustainable value chains: implications for value chain analysis. Supply Chain Management: An 
International Journal, 17(6), 575-581.

http://dx.doi.org/10.1108/13598541211269193

Feuz, D., Fausti, S. and J. Wagner (1993) Analysis of the efficiency of four marketing methods for slaughter cattle. Agribusiness - An International Journal 9: 453-463.

Feuz, D., Fausti and J. Wagner (1995) Risk and market participant behavior in the US slaughter-cattle market, Journal of Agricultural and Resource Economics, 20(1): 22-31.

Fousekis, P., Katrakilidis, C., \& Trachanas, E. (2016). Vertical price transmission in the US beef sector: Evidence from the nonlinear ARDL model. Economic Modelling, 52: 499-506.

Francis, M., David Simons, Michael Bourlakis, (2008) Value chain analysis in the UK beef foodservice sector, Supply Chain Management: An International Journal, 13(1): 83 - 91. http://dx.doi.org/10.1108/13598540810850346

Fukuyama, F. (2001). Social capital, civil society and development. Third World Quarterly, 22(1): 7-20. http://dx.doi.org/10.1080/713701144

Gellynck, X. and A. Molnar (2009) Chain governance structures: the European traditional food sector, British Food Journal, 111(8): 762-775. http://dx.doi.org/10.1108/00070700910980900

Gibbon, P. (2003) Value-chain Governance, Public Regulation and Entry Barriers in the Global Fresh Fruit and Vegetable Chain into the EU, Development Policy Review 21 (5-6): 615-625. DOI: 10.1111/j.1467-8659.2003.00227.x

Gómez, M. I., \& Ricketts, K. D. (2013). Food value chain transformations in developing countries: Selected hypotheses on nutritional implications. Food Policy, 42, 139-

150. http://dx.doi.org/10.1016/j.foodpol.2013.06.010

Gray, A., Boehlje, M. and P. V. Preckel (2006) Value chain risk and reward sharing and governance structures: Implications for industry strategy and structure, Journal on Chain and Network Science, 16(1): 45-54.

Grebitus, C., Steiner, B. and M. Veeman (2015). The roles of human values and generalized trust on stated preferences when food is labeled with environmental

footprints: Insights from Germany, Food Policy, 52: 84-91 http://dx.doi.org/10.1016/j.foodpol.2014.06.011

Gulati, R. (1998) Alliances and networks, Strategic Management Journal, 19: 293-317. DOI: 10.1002/(SICI)1097-0266(199804)19:4<293::AID-SMJ982>3.0.CO;2-

Gulati, R., and L. Wang (2003) Size of the pie and share of the pie: Implications of network embeddedness and business relatedness for value creation and value appropriation in joint ventures, Research in the Sociology of Organizations, 20: 209-242.

Gulati, A., Minot, N., Delgado, C. and S. Bora (2005) Growth in high-value agriculture in Asia and the emergence of vertical links with farmers, Paper presented at the workshop "Linking Small-Scale Producers to Markets: Old and New Challenges", The World Bank, 15 December 2005. 
Harri, A., Riley, J., Anderson, J. and K. Coble (2009) Managing economic risk in valuebased marketing of fed cattle, Agricultural Economics 40(3): 295-306. DOI:

10.1111/j.1574-0862.2009.00376.x

Hart, O. (1995) Firms, contracts and financial structure, Oxford University Press.

Hastings, K., Howieson, J., \& Lawley, M. (2016). Creating value chains: the role of relationship development. British Food Journal, 118(6), 1384-1406. http://dx.doi.org/10.1108/BFJ-10-2015-0389

Hennessy, D. (1996) Information asymmetry as a reason for food industry vertical integration, American Journal of Agricultural Economics, 78: 1034-43.

Hennessy, D., Roosen, J., Jensen, H. (2003). Systemic Failure in the Provision of Safe Food, Food Policy 28 (1): 77-96. http://dx.doi.org/10.1016/S03069192(03)00003-4

Henson, S., \& Humphrey, J. (2015). Assessing the Effectiveness of Agri-Food Value Chain Interventions Aimed at Enhancing Consumption of Nutritious Food by the Poor: Conceptual Framework. LANSA working paper No. 04, Leveraging Agriculture for Nutrition in South Asia (LANSA).

Howieson, J., Lawley, M., \& Hastings, K. (2016). Value chain analysis: an iterative and relational approach for agri-food chains. Supply Chain Management: An International Journal, 21(3). http://dx.doi.org/10.1108/SCM-06-2015-0220

Inkpen, A. and E. Tsang (2005) Social Capital, Networks, and Knowledge Transfer, Academy of Management Review, 30(1): 146-165.

Jensen, A. (2009) Valuation of non-timber forest products value chains, Forest Policy and Economics, 11: 34-41. http://dx.doi.org/10.1016/j.forpol.2008.08.002

Kepe, T. (2007) Medicinal plants and rural livelihoods in Pondoland, South Africa:

Towards an understanding of resource value, International Journal of Biodiversity Science and Management 3:170-183.

Kline, C. S., Joyner, L. E., Kirchoff, J. F., Crawford, A., Jilcott Pitts, S., Wall-Bassett, E., Gurganus, C. and Dunning, R. (2016). Gaps and barriers along the North Carolina agri-food value chain. British Food Journal, 118(2), 301-317. http://dx.doi.org/10.1108/BFJ-06-2015-0223

Kottila, M.-R. (2009) Knowledge sharing in organic food supply chains, Journal on Chain and Network Science, 9(2): 133-144.

Kristkova, Z. S., \& Coque, J. G. A. (2015). Competitiveness of the EU Beef Sector - a Case Study. AGRIS On-line Papers in Economics and Informatics, 7(2): 77.

Lagnevik, M., Sjoholm, I., Lareke, A. and J. Ostberg (2003) The Dynamics of Innovation Clusters: A Study of the Food Industry. Edward Elgar: Cheltenham.

Lavie, D. (2006). The competitive advantage of interconnected firms. Academy of Management Review 31 (3): 638-658.

Leek, S., Turnbull, P. and P. Naudé (2004) A comparison of manufacturers and financial services suppliers' and buyers' use of relationship management methods,

Industrial Marketing Management, 33(3): 241-249. http://dx.doi.org/10.1016/j.indmarman.2003.10.013 
Lange, D. (2002). Medicinal and aromatic plants: trade, production, and management of botanical resources. In: XXVI International Horticultural Congress: The Future for Medicinal and Aromatic Plants 629: 177-197.

Lewin, A., \& Minton, J. (1986). Determining Organizational Effectiveness: Another Look, and an Agenda for Research. Management Science, 32(5): 514-538.

Lutz, S. and T. Ritter (2009) Outsourcing, supply chain upgrading and connectedness of a firm's competencies, Industrial Marketing Management, 38(4): 387-393. http://dx.doi.org/10.1287/mnsc.32.5.514

Macharia, J., Collins, R., \& Sun, T. (2013). Value-based consumer segmentation: the key to sustainable agri-food chains. British Food Journal, 115(9), 1313-1328. http://dx.doi.org/10.1108/BFJ-09-2011-0215

Mainetti, L., Patrono, L., Stefanizzi, M. L., \& Vergallo, R. (2013). An innovative and low-cost gapless traceability system of fresh vegetable products using RF technologies and EPCglobal standard. Computers and electronics in agriculture, 98, 146-157.

Marsden, T., \& Smith, E. (2005). Ecological entrepreneurship: sustainable development in local communities through quality food production and local branding.

Geoforum, 36(4): 440-451. http://dx.doi.org/10.1016/j.geoforum.2004.07.008

Maunahan, M. V., Absulio, W. L., Esguerra, E. B., Sun, T., \& Collins, R. (2013). A value chain approach to developing export markets for 'Solo' papaya farmers in the Philippines. In II Southeast Asia Symposium on Quality Management in Postharvest Systems 1088: 277-282.

Menard, C. (2004) The Economics of Hybrid Organizations, Journal of Institutional and Theoretical Economics, $\quad$ 160: 345-376.

https://doi.org/10.1628/0932456041960605

Milgrom, P. and J. Roberts (1995) Complementarities and fit strategy, structure, and organizational change in manufacturing, Journal of Accounting and Economics 19: 179-208. http://dx.doi.org/10.1016/0165-4101(94)00382-F

Mishra, Divya, R. K. Singh, and R. K. Srivastava (2013). Agri-business and Entrepreneurship Development through Medicinal and Aromatic Plants: An Indian State of Affairs. International Journal of Food, Agriculture and Veterinary Sciences, 238-246.

Möller, K. (2007) Role of competences in creating customer value: A value-creation

logic approach, Industrial Marketing Management, 35: 913-924. http://dx.doi.org/10.1016/j.indmarman.2006.04.005

Nelson, R. R. (1994). The co-evolution of technology, industrial structure, and supporting institutions. Industrial and Corporate Change, 3(1): 47-63.

https://doi.org/10.1093/icc/3.1.47

OECD-FAO Agricultural Outlook 2015-2024, OECD Publishing, Paris. http://dx.doi.org/10.1787/agr_outlook-2015-en, www.fao.org/3/a-i4738e.pdf 
Ojasalo, J. (2004) Key network management, Industrial Marketing Management 33(3): 195-205. http://dx.doi.org/10.1016/j.indmarman.2003.10.009

Ostrom, E. (2010). Beyond markets and states: polycentric governance of complex economic systems. Transnational Corporations Review, 2(2), 1-12.

Oxley, J. E. (1997). Appropriability hazards and governance in strategic alliances: A transaction cost approach. Journal of Law, Economics, and Organization, 13(2): 387-409. https://doi.org/10.1093/oxfordjournals.jleo.a023389

Pancino, B., Pascucci, S., Blasi, E., Ruini, L., \& Ronchi, C. (2016). The role of network creation and actor engagement in the adoption and diffusion of sustainable innovations in food value chains. Rivista di Economia Agraria, 71(1), 78-85.

http://dx.doi.org/10.13128/REA-18628

Pang, Z., Chen, Q., Han, W., \& Zheng, L. (2015). Value-centric design of the internet-ofthings solution for food supply chain: value creation, sensor portfolio and information fusion. Information Systems Frontiers, 17(2): 289-319.

Piltan, M., \& Sowlati, T. (2014). A review of partnership studies in the forest products value chain: with a focus on developed countries (United States, Canada, and Western Europe). Forest Products Journal, 64(1): 4-10.

http://dx.doi.org/10.13073/FPJ-D-13-00076

Polkinghorne, R., Thompson, J. M., Watson, R., Gee, A., \& Porter, M. (2008). Evolution of the Meat Standards Australia (MSA) beef grading system. Animal Production Science, 48(11), 1351-1359.

Polkinghorne, R. J., Thompson, J., Hocquette, J. F., \& Pethick, D. (2015). Overview of Meat Standards Australia (MSA) and cuts based grading schemes. Meat Research, 29(2): 43-48.

Porter, M.E. (1985) Competitive Advantage, Free Press, New York.

Porter, M.E. (1987) From Competitive Advantage to Corporate Strategy, Harvard Business Review, May/June: 43-59.

Priem, R. and J. Butler (2001) Is the resource-based "view" a useful perspective for strategic management research? Academy of Management Review, 26(1): 22-40.

doi: 10.5465/AMR.2001.4011928

Priem, R. (2007) A consumer perspective on value creation, Academy of Management Review 32(1): 219-235. doi: 10.5465/AMR.2007.23464055

Rao, M. R., Palada, M. C., \& Becker, B. N. (2004). Medicinal and aromatic plants in agroforestry systems. Agrofoerstry Systems, 61: 107-122.

Reardon, T. (2015). The hidden middle: the quiet revolution in the midstream of agrifood value chains in developing countries. Oxford Review of Economic Policy, 31(1), 45-63. https://doi.org/10.1093/oxrep/grv011

Ritter, T., Wilkinson, I. and W. J. Johnston (2004) Managing in complex business networks, Industrial Marketing Management, 33(3) 175-183. http://dx.doi.org/10.1016/j.indmarman.2003.10.016

Rosemann, M., \& vom Brocke, J. (2015). The six core elements of business process 
management. In: Handbook on Business Process Management 1 (pp. 105-122). Springer Berlin Heidelberg.

Schwarz, G.M., and Stensaker, I.G., (2016). Showcasing phenomenon-driven research on organizational change, Journal of Change Management, 16: 245 - 264. http://dx.doi.org/10.1080/14697017.2016.1230931

Shah, R. H., \& Swaminathan, V. (2008). Factors influencing partner selection in strategic alliances: The moderating role of alliance context. Strategic Management Journal, 29(5): 471-494. DOI: $10.1002 / \mathrm{smj} .656$

Shank, J.K., and V. Govindarajan (1992) Strategic cost management: the value chain perspective. Management Accounting Research 4: 177-197.

Siebert, J. W., \& Jones, C. (2013). A case study on building the certified Angus beef® brand. International Food and Agribusiness Management Review, 16(3), 195-208.

Singh, K. M. (2005) Development of Supply Chains for Medicinal Plants: A Case Study Involving the Production of Vinca Rosa by Small Farmers in the Patna District of Bihar India, mimeo, 16p, accessed 03/04/09. http://www.globalfoodchainpartnerships.org/cairo/papers/KMSinghIndia.pdf,

Simons, D., Francis, M., Bourlakis, M. and A. Fearne (2003) Identifying the determinants of value in the U.K. red meat industry: A value chain analysis approach, Journal on Chain and Network Science, 3(2): 109-121.

Soji, Z., Chikwanda, D., Chikwanda, A. T., Jaja, I. F., Mushonga, B., \& Muchenje, V. (2015). Relevance of the formal red meat classification system to the South African informal livestock sector. South African Journal of Animal Science, 45(3), 263-277. http://dx.doi.org/10.4314/SAJAS.V45I3.5

Spanyi, A. (2015). The governance of business process management. In: Handbook on Business Process Management 2 (pp. 333-349). Springer Berlin Heidelberg.

Stam, W., Arzlanian, S. and Elfring, T. (2014). Social Capital of Entrepreneurs and Small Firm Performance: A Meta-Analysis of Contextual and Methodological

Moderators, Journal of Business Venturing, 29: 152-173. http://dx.doi.org/10.1016/j.jbusvent.2013.01.002

Steiner, B. (2006) Governance Reform of German food safety regulation: Cosmetic or real? in: European Food Safety Regulation: The Challenge of Multi-Level Governance (eds. Chris Ansell, and David Vogel), MIT Press, pp.181-210, http://mitpress.mit.edu/catalog/item/default.asp?ttype=2\&tid=10858

Steiner, B. (2007) Negotiated transfer pricing: Theory and implications for value chains in agribusiness, Agribusiness: An international journal, 23(3): 279-292. DOI: 10.1002/agr.20117

Steiner, B. (2012). Contracting in the wine supply chain with bilateral moral hazard, residual claimancy and multitasking, European Review of Agricultural Economics, 39(3): 369-395. https://doi.org/10.1093/erae/jbr054

Steiner, B., Unterschultz, J. and E. Goddard (2007) Formal beef alliances and alignment challenges: Issues in contracting, pricing and quality, Department of Rural Economy, Project Report: \# 07-02, 2007, 94p. http://www.rees.ualberta.ca/en/Research/ProjectReports.aspx

Steiner, B. and J. Yang (2010). How do consumers value credence attributes associated 
with beef labels since the North American BSE crisis of 2003? International Journal of Consumer Studies, 34(4): 449-463. DOI: 10.1111/j.14706431.2010.00889.x

Steiner, B., Lan, K.; John, G.; Unterschultz, J.; Laate, E.; Goddard, E. and P. Boxall (2014) Vertical Coordination and Competition in North Americas Beef Value Chain: Evidence from Canada. in: C.S. Sundaresan (ed.) Farm Value Chains for Sustainable Growth \& Development (2014), Regal Publications, New Delhi: 213242, ISBN 978-81-8484-318-7.

Steiner, B. and C. Wang (2016). Social capital, religious affiliation and business performance in Denmark, Academy of Management Proceedings, doi: 10.5465/AMBPP.2016.291.

Steiner, B., Lan, K., Unterschultz, J. and P. Boxall (2017). Applying the Resource-BasedView to Alliance Formation in Specialized Supply Chains, Journal of Strategy and Management, in print..

Stockwell, B. R., Bradley, E., Davis, D., \& Smith, J. (2016). Peri-Urban Food Futures: Opportunities and Challenges to Reconfiguring Sustainable Local Agri-food Value Chains on the Sunshine Coast, Australia. Journal of Agriculture, Food Systems, and Community Development, 4(1): 123-140. http://dx.doi.org/10.5304/jafscd.2013.041.001

Taylor, D. H. (2005). Value chain analysis: an approach to supply chain improvement in agri-food chains. International Journal of Physical Distribution \& Logistics

Management, 35(10): 744-761. http://dx.doi.org/10.1108/09600030510634599

te Velde, D.W., Rushton, J., Schreckenberg, K., Marshall, E., Edouard, F., Newton, A. and E. Arancibia (2006) Entrepreneurship in value chains of non-timber forest products, Forest Policy and Economics, 8: 725-741. http://dx.doi.org/10.1016/j.forpol.2005.06.010

Teece, D. J. (1986). Profiting from technological innovation: Implications for integration, collaboration, licensing and public policy. Research Policy, 15(6): 285-305. http://dx.doi.org/10.1016/0048-7333(86)90027-2

Tieguhong, J. C., Ingram, V., Mala, W. A., Ndoye, O., \& Grouwels, S. (2015). How governance impacts non-timber forest product value chains in Cameroon. Forest Policy and Economics, 61, 1-10. http://dx.doi.org/10.1016/j.forpol.2015.08.003

Tirole J. (1988) The theory of industrial organization. Cambridge, M.A., MIT Press. Tronstad, R. and J. Unterschultz (2005) Looking Beyond Value-Based Pricing of Beef, Supply Chain Management: An International Journal 10(3): 214-222. http://dx.doi.org/10.1108/13598540510606278

Tsai, M. C., Lai, K. H., \& Hsu, W. C. (2013). A study of the institutional forces influencing the adoption intention of RFID by suppliers. Information \& Management, 50(1), 59-65. http://dx.doi.org/10.1016/j.im.2012.05.006

Uddin, M., Quaddus, M. and N. Islam (2010) Knowledge Asset and Inter-Organizational 
Relationship in the Performance of Australian Beef Supply Chain, PACIS 2010

Proceedings. Paper 21 (http://aisel.aisnet.org/pacis2010/21).

Van de Ven, A. H. (2016). Grounding the research phenomenon. Journal of Change Management, 1-6.

Van Engelen, A., \& Keyser, J. (2013). Botswana agrifood value chain project: beef value chain study. Rome: Food and Agriculture Organisation (FAO).

Verdouw, C. N., Beulens, A. J. M., \& Van Der Vorst, J. G. A. J. (2013). Virtualisation of floricultural supply chains: A review from an Internet of Things perspective. Computers and Electronics in Agriculture, 99, 160-175.

Walters, D., \& Lancaster, G. (1999). Value-based marketing and its usefulness to customers. Management Decision, 37(9), 697-708. http://dx.doi.org/10.1108/00251749910299066

Wernerfelt, B. (1984) A resource based view of the firm, Strategic Management Journal, 5: 171-180. DOI: $10.1002 / \mathrm{smj} .4250050207$

Wiersum, K. F., Ingram, V. J., \& Ros-Tonen, M. A. F. (2014). Governing access to resources and markets in non-timber forest product chains. Forests, Trees and Livelihoods, 23(1-2), 6-18. http://dx.doi.org/10.1080/14728028.2013.868676

Wijnands, J. and C. Ondersteijn (2006) Supply chain organization and chain performance, in: Ondersteijn, C. Wijnands, J. R. Huirne and O. van Kooten (eds.) Quantifying the Agri-Food supply Chain, Springer Verlag Netherlands, pp.3-12.

Williamson, O. (1985). The economic institutions of capitalism: Firms, markets, relational contracting. New York: The Free Press.

Williamson, O. (1993). Calculativeness, trust, and economic organization, Journal of Law and Economics, 36: 453-486. DOI: 10.1086/467284

Woodruff, R. B. (1997). Customer value: the next source for competitive advantage. Journal of the academy of marketing science, 25(2): 139-153.

doi:10.1007/BF02894350

Wulf, D., O’Connor, S., Tatum, J. and G. Smith (1997) Using Objective Measures of Muscle Color to Predict Beef Longissimus Tenderness. Journal of Animal Science 75: 684-92. doi:10.2527/1997.753684x

Zablah, A., Bellenger, D. and W. Johnston (2004) An evaluation of divergent perspectives on customer relationship management: Towards a common understanding of an emerging phenomenon Industrial Marketing Management, 33(6): 475-489. http://dx.doi.org/10.1016/j.indmarman.2004.01.006

Zahra, S. A., \& George, G. (2002). Absorptive capacity: A review, reconceptualization, and extension. Academy of management review, 27(2), 185-203. doi: 10.5465/AMR.2002.6587995 